\title{
DETERMINANT FACTORS FOR UNIVERSITY STUDENT DROPOUT: A STUDY WITH NEW STUDENTS OF ACCOUNTING SCIENCES COURSES AT FEDERAL UNIVERSITIES IN THE NORTHEAST REGION
}

\author{
Sulanny de Souza Sampaio' \\ Maria Marcela Ramos da Rocha² \\ Sueli Maria de Araújo Cavalcante ${ }^{3}$ \\ Maxweel Veras Rodrigues ${ }^{4}$
}

Abstract:

Objectives: To identify the determinant factors for student dropout in Accounting Sciences courses at Federal Universities in the Northeast region.

Methods: This is a descriptive-exploratory study with a quantitative approach and survey usage. The sampling is non-probabilistic and intentional, covering all federal universities in the Northeast region of Brazil and consisting of 220 students who had enrolled in Accounting Science Courses in 2019. A questionnaire adapted from Cunha, Nascimento and Durso (2016) was also used, and data were interpreted through descriptive and factor analysis.

Results or discussion: The results showed us that the vocational factor with the greatest factor loading was the one related to the type of admission, resulting from a successful selection process for the course in question and not for the student's preferred course. The most relevant institutional factor was related to the lack of information about the course as provided by the institution. The students' perception of the performance factor showed that the item with the highest factor loading was the one related to the student's difficulty in following the course because he or she did not have enough time to study. Contributions: The results indicate that the institution, with the information provided, may act directly upon the identified weaknesses through specific actions in order to reduce dropout rates.

Keywords: student dropout; accounting sciences; higher education.

\footnotetext{
sulanny@ufc.br. Universidade Federal do Ceará. Fortaleza-CE, Brasil. https://orcid.org/0000-0002-4992-0604

marcela@ufc.br. Universidade Federal do Ceará. Fortaleza-CE, Brasil. https://orcid.org/0000-0002-7005-7200

suelicavalcante@ufc.br. Universidade Federal do Ceará. Fortaleza-CE, Brasil. https://orcid.org/0000-0002-0698-2485

${ }_{2}^{2}$ maxweelveras@gmail.com. Universidade Federal do Ceará. Fortaleza-CE, Brasil. https://orcid.org/0000-0003-1999-6832

- DOI: http://dx.doi.org/10.14392/asaa.2020130305

- Artigo submetido em: 07/06/2020. Submetido a nova rodada em: 18/08/2020. Aceito em: 26/10/2020

- O presente artigo foi divulgado nos anais do XIX Colóquio Internacional de Gestão Universitária - CIGU 2019, realizado na Universidade Federal de Santa Catarina - UFSC nos dias 25,26 e 27 de novembro de 2019 .
} 


\section{FATORES DETERMINANTES PARA A EVASÃO UNIVERSITÁRIA: UM ESTUDO COM INGRESSANTES DO CURSO DE CIENCIAS CONTÁBEIS DE UNIVERSIDADES FEDERAIS DA REGIÂO NORDESTE}

Resumo:

Objetivos: Identificar os fatores determinantes para a evasão de estudantes do curso de Ciências Contábeis em Universidades Federais do Nordeste.

Método: Trata-se de uma pesquisa descritiva-exploratória com abordagem quantitativa e survey. A amostra foi do tipo não probabilística e intencional, constituída por 220 estudantes ingressantes no ano 2019, no Curso de Ciências Contábeis, abrangendo todas as universidades federais da região nordeste do Brasil. Como instrumento de pesquisa foi utilizado um questionário adaptado de Cunha, Nascimento e Durso (2016). A interpretação dos dados foi realizada fazendo uso de análise descritiva e análise fatorial. Resultados ou discussões: Os resultados nos apontaram que o fator vocacional com maior carga fatorial foi aquele relacionado a forma de ingresso, decorrente do sucesso no processo seletivo para o curso em questão e não para o curso de preferência do discente. $O$ fator institucional mais relevante foi relacionado a falta de informações sobre o curso por parte da instituição. A percepção dos alunos quanto ao fator desempenho mostrou que o item com maior carga fatorial foi aquele relacionado a dificuldade do discente em acompanhar o curso por não possuir tempo necessário para o estudo. Contribuições: Esses resultados nos indicam que a instituição, de posse dessas informações, pode atuar diretamente nas fragilidades identificadas, através de ações específicas, objetivando reduzir a evasão.

Palavras-chave: Evasão, Ciências Contábeis, Educação Superior. 


\section{INTRODUCTION}

$\mathrm{T}$ he last decade was marked by an increased access to higher education in Brazil, as a result of government actions legitimized by federal laws. Maués (2019) states that this increase stems from the fact that institutions in countries like Brazil have been concerned inadvancing towardsthe guidelines specified by international organizations, such as the World Bank and the Organization for Cooperation for Economic Development (OECD), which assert that higher education enables a new type of social organization, in addition to playing an important role in a country's economic growth.

Both public and private higher education institutions have witnessed an increasing demand for qualification, although the private sector is responsible for offering a greater number of vacancies than that of the public sector (Vieria, Troccoli \& Silva, 2011). In other countries, this growth, which was also remarkable and happened in the same way as in Brazil, raised questions about how successful the academic performance is and, mainly, about the permanence of university students (Ambiel, Santos \& Dalbosco, 2016; Araújo, Almeida, Costa, Alfonso, Conde \& Deaño, 2015), as it is increasingly possible to identify the occurrence of dropout in higher education.

According to Silva, Miranda, Leal and Pereira (2018) the dropout rate in distance learning undergraduate courses corresponds to $28.8 \%$, whereas the face-to-face learning dropout rate corresponds to $24.9 \%$. They also identified in their findings that the average dropout rates were statistically similar in both public and private institutions.

This context points to a concern in relation to the need to create mechanisms that lead to the permanence of these students, in such a way that it allows for the reduction of factors that can lead them to drop out of the long-dreamed higher education course. Authors such as Ambiel (2015), Ambiel et al. (2016), Hoffmann, Nunes, Muller and Hoffmann (2016), started researching this issue in order to learn about some of the reasons that cause this dropout, and to eventuallydevelop effective actions that reduce it.

Ambiel et al. (2016) analyzed how much the academic and career adaptability variables were able to predict reasons for dropping out of higher education. They carried out a study with 153 university students from a private higher education institution and concluded that investing in student retention involves good relationship conditions and general well-being, in addition to access to possibilities for the development of skills in order to face career decisions.

In the view of the course coordinators, this issue was addressed in the research by Silva et al. (2018), who analyzed and identified the perception of the course coordinators regarding the student retention actions applied in the Accounting courses in Brazil and their relation to the dropout rate of Higher Education Institutions (HEI). The sample consisted of 155 coordinators linked to private and public HEls from all regions of Brazil. The results showed that the HEls in which the coordination promotes the students' academic integration through actions such as monitoring and intervention regarding teaching and learning difficulties during the course, monitoring the attendance, as well as offering guidance about the course during enrollment, tend to have lower dropout rates.

Focusing on the public context, Cunha, Nascimento and Durso (2016) addressed the dropout issue in order to seek evidence that would make it possible to discern the reasons that could influence the dropout of Accounting students from public HEls in the Southeast region of Brazil during their first year at college. The authors prepared, validated and applied a questionnaire to 348 newly enrolled students at 6 federal universities in Southeastern Brazil in2013. The results showed that students do not seem 
likely to drop out of the course and the authors concluded that such results may indicate that students entered the course feeling significantly enthusiastic about it, although there are indications that the choice of the course was not a well-oriented process.

We have observed that the dropout issue is very relevant, especially in the context of public institutions, since properly applied public resources can help expand services to a larger number of citizens, and idle vacancies tend to reflect misuse of public resources.

We have also identified a gap in the investigation of this subject in the Northeast region of Brazil, which makes the research pertinent because it produces concrete data on the subject, in addition to expanding the theoretical framework.

In face of this context, the study seeks to answer the following research question: What are the determinant factors for university dropout in the perception of students in the first semester of the Accounting Sciences Course at federal universities in the Northeast region of Brazil? In order to answer this problem, the aim of this research is to identify the determinant factors for university dropout in the perception of students in the first semester of the Accounting Sciences Course at federal universities in the Northeast of Brazil.

From this perspective, we understand that the results of the present study provide a relevant institutional, academic and social contribution. Under the institutional aspect, this study contributes by providing accurate and reliable information about the reality of the factors considered by Accounting students in the Northeast region, thus providing benefits that may assist institutional managers in the development of effective strategies to reduce dropout. From an academic standpointthis studymay be used in subsequent consultations considering the theoretical basis presented and, thus, promote the scientific densification of the study's theme.Moreover, with regard to social relevance, we emphasize the importance of identifying students' socioeconomic characteristics and their perception of the reception they got in the first year of the course in relation to their peers, teachers, coordinators and institution.

\section{THEORETICAL FOUNDATION}

2.1 Dropout in Higher Education

The changes that occurred in Brazilian higher education in the last decades of the 2000's are noteworthy, as they include an expanded offer of higher education courses by several new colleges both in the public and private sectors, in addition to the increase in courses in the distance learning modality and also the democratization of the enrollment in higher education through PROUNI (University For All Program), social and racial quotas, expansion of FIES (Student Financing Fund) and SiSu (Unified Selection System), making it possible for students from one state to attend higher education in another.

The search for the expansion of higher education is not recent, however. The approval of the first Law of Directives and Bases for National Education (LDB) was remarkable for education, because, according to the Ministry of Education (MEC) portal, the Brazilian educational system until 1960 was centralized and such model was adopted by all states and municipalities. With the approval, the state and municipal agencies gained more autonomy, reducing the centralization of the MEC (MEC, 2015).Furthermore, the LDB promoted a university reform that took place in the military government (1964-1985), a time in which there were actions to expand higher education, but ended up benefitting private higher education institutions more directly, even with the aid of public funding for this form of education (Silva, 2016). 
It only became possible to observe a small expansion of access to higher education with the promulgation of the 1988 Constitution and later with a new reform in Brazilian education through Law 9.394 / 96, the Law of Directives and Bases for National Education.

Ristoff (2014) divides such changes after the new LDB into two moments: one between 1999 and 2003 , with the increase of private institutions, and a second subsequent moment, with a more balanced increase due to social inclusion policies.

The transformations identified in public higher education are the result of the implementation of public policies by the federal government, such as the Support Program for Federal University Restructuring and Expansion Plans (REUNI), which aims to make this form of education accessible to all social levels, democratizing enrollment and expanding the growth of public institutions of higher education.

REUNI was established in 2007 by Decree No. 6,096, which intended to restructure and expand higher education. This expansion on the number of vacancies available also led to an increase in dropout rates from higher education courses. Thus, in the guidelines set out in Art. 2, the program included the expansion of inclusion and student assistance policies and the reduction of dropout rates (Brasil, 2007).

This scenario led to the necessary creation of the National Student Assistance Program (PNAES) in 2007 , in order to allow higher education students to remain in university until the conclusion of the course. Gilioli (2016) argues that the PNAES, among other things, aims to contribute to the improvement of academic performance and to act preemptively in cases of term repetition and dropout resulting from insufficient financial conditions.

However, PNAES' actions on their own are not enough to guarantee the reduction of dropout numbers, it is necessary to understand how the phenomenon occurs and which factors motivate its incidence. There are few Brazilian institutions that have professionalized institutional support to combat dropout. This may be a reflection of the lack of a student retention policy and will continue as long as the institutions do not make an effort to fight it.

According to Gaioso (2005), dropout is a complex social phenomenon that is defined as an interruption in the study cycle. It is a problem that has been worrying educational institutions in general, whether public or private, because the departure of students causes serious social, academic and economic consequences.

The Special Commission for the Study of Dropout Rates by the Secretariat of Higher Education/Ministry of Education and Sport [SESu/MEC] (1997) states in its report that "student dropout is a complex phenomenon common to university institutions in the contemporary world. Precisely for this reason, its complexity and scope have been the subject of studies and analyses in recent years, especially in First World countries". (p.18)

The Special Commission for the Study of Dropout Rates[SESu/MEC](1997), despite considering dropout as the student's definitive departure from his or her course of origin without due conclusion, also conceptualized it as follows:

a) Dropout from the course: the student leaves the higher education course in various situations, such as abandonment (fails to enroll), dropout (official), transfer or re-option (course change), exclusion by institutional rule;

b) Dropout from the institution: the student leaves the institution in which he or she is enrolled;

c) Dropout from the system: the student permanently or temporarily leaves higher education

According to Gaioso (2005), dropout is a complex problem, resulting from a combination of several factors that weigh on the student's decision to stay or not in the course. The author established a rela- 
tionship between the dropout phenomenon and its possible factors, such as repetition, course change, career guidance and counseling, the career's (lack of) prestige, work schedule and (lack of) motivation, as shown in Table 1.

Table 1 - Possible factors causing dropout

\begin{tabular}{|c|c|}
\hline Factor & Discrimination \\
\hline Repetition & There is evidence that after failing courses students are more likely to drop out of undergraduate courses. \\
\hline Career guidance and counseling & $\begin{array}{l}\text { The lack of information about the profession and the course they enrolled in leads many students to drop } \\
\text { out. Upon realizing that he or she acted out of unfounded expectations regarding the chosen institution } \\
\text { or profession, the student is disappointed with the higher education course and institution and begins to } \\
\text { consider the possibility of dropping out. }\end{array}$ \\
\hline Course change & $\begin{array}{l}\text { There are studies that call attention to the significant number of students who change courses at the } \\
\text { same HEl or cancel enrollment because they have been approved at another public or private institution. }\end{array}$ \\
\hline The career's (lack of) prestige & $\begin{array}{l}\text { Another reason, commonly evidenced in research on course dropout, is related to the job market and the } \\
\text { prestige of the career chosen when signing up for the entrance exam. }\end{array}$ \\
\hline Work schedule & The difficulty in balancing work hours and school hours is a major factor in the decision to leave college. \\
\hline (Lack of) motivation & $\begin{array}{l}\text { Upon entering higher education, the student is motivated, among other reasons, by the expectation of } \\
\text { better living conditions and professional achievement. However, being accepted into and enrolling in } \\
\text { a higher education institution does not guarantee that motivation will remain and that the student will } \\
\text { continue the course. }\end{array}$ \\
\hline
\end{tabular}

Source: Gaioso (2005)

Dropout is a problem that affects all educational institutions, whether public or private and at all levels of education. Failure to complete the course and its dropout lead to a collective loss, as all involved, whether students, institution, teachers, government and society at large, are hampered by the investment that failed to wield results and by the time spent without achieving the goal, among other losses that may be academic, economic and social (Lobo, 2012).

Spady and Tinto conducted studies on the subject of dropout, their theories based on Emile Dukheim's Study of Suicide. The first emphasizes the process of integrating student attributes, values, interests, skills and attitudes with the norms of the university environment. If there is harmony between the student and the institution, he or she will assimilate the social and academic challenge, and his or her chances of permanence will be greater (Cislaghi, 2008).

Tinto's Integration Model consists of two dimensions: internal, due to factors arising from the experience that precedes the student's entry into the course and the individual characteristics of this student; and integration, focused on the experiences lived during the course. Tinto identified several types of behavior and classified them as academic failure, voluntary dropout, abandonment, temporary removal and transfer (Cislaghi, 2008).

In 1993, Tinto revises his model and adds the components finances, adjustment, difficulty, learning, incongruity and external commitments, due to the recognition of the influence of internal and external factors in the occurrence of dropout (Cislaghi, 2008; Silva et. al. 2018)

Another relevant theory about dropout is the one proposed by Bean, called Nontraditional Student Attrition Model, which considered the characteristics of the students who could not fully throw themselves into their studies, a reality that is similarly shared with Accounting students. In his model, Bean considered the variables that influence student attrition and that could lead the student to drop out of university (Silva, Cunha, Durso \& Nascimento, 2014). These variables include non-cognitive factors, such as attitudes and behavioral intentions, and environmental factors, such as support from family and friends. Beliefs influence the development of attitudes that lead to the definition of behavioral intentions.

In the 1990s, Cabrera, Castañeda, Nora and Hengstler developed the Integrated Model of Student Retention based on the Tinto and Bean models, later perfected by Cabrera, Nora and Castañeda, establishing the 10 elements that can lead the student to give up the course (Silva et al. 2014). As it is a 
model that includes elements from other models, thus enabling the identification of a greater range of factors that can motivate evasion, this is the theory that best fits this study.

\title{
2.2 Related research
}

The importance of understanding the dropout phenomenon has motivated the development of various academic research that, in most cases, aim to understand the causes of the significant increase in the number of students entering higher education and opting to drop out. Taking into account the real and potential difficulties that dropout may cause at both the individual, institutional and social levels, some authors have been making efforts to understand the reasons why students choose to drop out. According to Berger and Lyon (2005 as cited in Cislaghi, 2008, p. 37):

\begin{abstract}
A synthesis of the evolution of studies and scientific developments on student dropout and retention would begin in the 1950s, in the USA, when there was a large expansion in the number of HEls and the number of university students. At the end of World War II, there was a great need for higher-educated human resources to meet the growing demands of an industrializing society that would accelerate a permanent search for technological advances. (Berger \& Lyon, 2005, as cited Cislaghi, 2008, p. 37).
\end{abstract}

In Brazil, as mentioned by Schuarcz, Sá, Warmuth, and Maçaneiro (2013), the most comprehensive study on the subject of dropout from Brazilian universities was conducted in 1995 by the Secretariat of Higher Education (Sesu) of the Ministry of Education and Culture (MEC). After its proposal, the creation of a Special Commission of Evasion Studies in the Brazilian public universities happened in the following year and comprehended the public agencies: Andifes, Abruem, Sesu and MEC. The research conducted by this commission covered 61 federal and state Public Higher Education Institutions, representing $77.2 \%$ of the universe of public higher education in the country. The initiative to create the Special Evasion Studies Commission in 1995 was to understand, among other factors, the low graduation rates in public institutions (Brasil, 1997).

Silva Filho, Montejunas, Hipólito and Lobo (2007), in a study conducted in 2007, affirm the need to understand dropout under two similar but not identical aspects:

a) Average annual dropout: measures the percentage of students enrolled in an education system, in an $\mathrm{HEl}$, or a in course, who, having not graduated, have not enrolled in the following year as well.

b) Total dropout: measures the number of students who, having entered a particular course, $\mathrm{HEl}$ or education system, have not obtained a diploma after a certain number of years.

Ambiel (2015) developed a study on dropout by sourcing previous studies, higher education students and experts with experience in the subject (PhD students with research in the area). The study consisted of two stages; in the first one, based on information gathered from those involved, 81 predictors of dropout were listed. The second stage consisted of applying a five-point Likert scale questionnaire, which ranged from "very weak" to "very strong" and contained the 81 items ascertained in the previous phase, to a sample of 327 higher education students, aged between 17 and 58 years old, from public and private institutions located in all Brazilian states, including the Federal District.

After the analysis of the results, out of the 81 investigated items, 15 were discarded, generating the Higher Education Dropout Motives Scale (M-ES), containing 66 dropout motivating factors in its structure. The author divided the factors into groups entitled: institutional reasons (including faculty, infrastructure deficiencies), personal reasons (uncertainties regarding course choice, family aspects), 
reasons related to lack of support (financial, personal and family difficulties), career-related reasons (career and job market concerns), academic-related reasons (subject performance), interpersonal reasons (peer relationships), and autonomy-related reasons (difficulties living outside the family home).

Another study by Ambiel, Carvalho, Moreira and Bacan (2016) intended to verify the adequacy of M-ES and investigate the presence of differential functioning of items according to the type of institution, whether public or private. The research involved 327 university students, aged 17 to 58 years, from public and private institutions from all Brazilian states, including the Federal District. The research found that, of the 7 categories (institutional reasons, personal reasons, lack of support reasons, career related reasons, academic related reasons, interpersonal reasons and autonomy related reasons), 5 presented at least one item with differential functioning. Of these, the content related to financial difficulties were scored more frequently by private universities, since the student is responsible for the course financing. Regarding students from public institutions, the most significant content was related to the institution itself (physical, academic structure, lack of support, especially family).

Hoffmann et al. (2016) also attempted to identify the factors that most influence the dropout of higher education students. The study was conducted at the Federal University of Santa Maria (UFSM) and was based on the knowledge of experts on the subject matter. The authors carried out the research in two stages; in the first one a survey was made out of the information available in the UFSM database about the students entering, graduating and currently enrolled in the institution, from 2009 to 2014. Then, a questionnaire was applied to 19 experts on the subject matter (all PhDs), in which those involved gave opinions on the factors influencing dropout. Stage 1 identified that dropout at UFSM has higher rates in courses in Linguistics, Languages and Arts, while courses in Health Sciences showed the lowest occurrence of the phenomenon. In the second stage, it was found that among the researched aspects, the experts pointed the personal and motivational aspects of the students as the strongest, and among them the issue of "failure when properly choosing a course" was identified as the one that most motivates the dropout among higher education students.

Within the scope of the Accounting Sciences course, Cunha et al. (2016) studied the topic of dropout in order to identify possible reasons that could influence the dropout of students in the first year of the Accounting course at federal universities in the Southeast region. In the research by Silva, Nasu, Leal and Miranda (2020), the authors addressed the topic at the national level and analyzed the factors related to dropout in the Accounting course, aiming to map which characteristics of the students, the course and the Higher Education Institutions were determinant in the dropout phenomenon.

Dropout is, thus, a complex issue and the understanding of the reasons involved in the student's decision to drop out is pertinent to the development and implementation of strategies aimed at reducing this phenomenon in institutions, whether public or private. Each type of institution has distinct specificities and need measures to combat dropout focused on their particularities.

\section{METHODOLOGY}

This research is characterized as descriptive, with a quantitative approach. It is descriptive due to its purpose in identifying the factors considered determinant for the dropout of students of Accounting Sciences courses in public HEl in the Northeast region in their first year of the undergraduate program. Whereas its quantitative aspect stems from its usage of statistical resources, which helped ensure the 
accuracy of the results and avoid distortions in order to achieve a safety margin regarding the inferences made (Beuren, 2008).

The technical procedures for data collection are classified as survey. The population consisted of students from the 12 Federal Universities of the Northeast region that offer the Accounting program per the MEC website, as seen on 05.31.2019.

Our sample was non-probabilistic and intentional (Gil, 2010), as it was composed of first-year students from the Accounting courses who were available for research participation at the Federal Universities of Northeast Brazil (Table 2). It represented $25 \%$ of the total students.

A questionnaire was chosen as the data collection tool for this study, and we further adapted itfrom the previously developed and validated questionnaire by Cunha et al. (2016). The questionnaire consisted of the identification of the student's profile, the academic profile and the Identification of the Motivating Factors for Dropout.

Table 2: Federal Universities of the Northeast Region of Brazil which offer the Accounting Science course

\begin{tabular}{|c|c|c|}
\hline Name & Acronym & State \\
\hline Federal University of Alagoas & UFAL & AL \\
\hline Federal University of Bahia & UFBA & CE \\
\hline Federal University of Cariri & UFCA & CE \\
\hline Federal University of Ceará & UFC & MA \\
\hline Federal University of Maranhão & UFMA & PB \\
\hline Federal University of Paraíba & UFPB & PB \\
\hline Federal University of Campina Grande & UFCG & PE \\
\hline Federal University of Pernambuco & UFPE & PI \\
\hline Federal University of Piauí & UFPI & RN \\
\hline Federal University of Rio Grande do Norte & UFRN & RN \\
\hline Federal Rural University of the Semi-Arid & UFERSA & SE \\
\hline Federal University of Sergipe & UFS & \\
\hline
\end{tabular}

The first part of the questionnaire aimed to outline the respondents' socioeconomic profile, with questions such as sex, marital status, age, parents' level of education, family income, type of institution where he or she attended most of high school and whether the respondent takes part in any other activity.

The second part aimed to collect information about the respondents' academic profile through objective questions and about the students' adaptation process in the first year of the undergraduate program, involving colleagues, teachers, course coordinators, institution and study routines, through statements in a Likert scale ranging from 1 to 5 and varying from "Terrible" to "Very Good", as used by Cunhaet al. (2016).

The third and last part consisted of 20 questions, containing the variables that would be more likely to influence students to drop out of undergraduate courses (Cunha et al. 2016). Respondents assigned a score from 0 to 10 for each of these items, where 0 (zero) corresponds to "does not influence" and, 10 (ten), to "strongly influences".

We collected the survey data through contact with coordinators by telephone and email, who in turn shared the questionnaire directly with new students in 2019 via Google Forms. Other institutions 
provided the list of students with their respective emails. In such cases, the questionnaire was sent via Google Forms, between June and July 2019. It is worth mentioning that at the Federal University of Ceará the questionnaire was applied in person. For data treatment and analysis, we used the statistical software Minitab.

\section{ANALYSIS AND DISCUSSION OF RESULTS}

This section presents the analysis and interpretation of the data obtained from the answers provided by Accounting students regarding the determinant factors for university dropout.

\subsection{Descriptive analysis}

Firstly, it is worth mentioning that we received 220 valid, and, in cases where the respondent omitted his or her answer, we considered it "Not Informed (NI)".

The number of respondents under the age of 20 represented more than half of the sample (54.5\%), as shown in Table 3, which confirms the census conducted by MEC (2018) that stated that students entering higher education tend to be only 18 years old. This piece of information was obtained considering the mode of the answers of the item in question. This result is very positive as it shows that young people have the opportunity to enter higher education at an earlier age and thus become more competitive in the job market. In addition, the present research identified that these young people are mostly single (86.4\%).

Despite the profile drawn by the MEC census (2018), which shows that female students are predominant in higher education courses, thus corroborating the survey by Cunha et al. (2016) where females represented $50 \%$ of students entering the course of Accounting Sciences in the Southeast in 2013 , the Northeast region seemed to differ from this result, as 54\% of the newcomers in 2019 represent the male sex.

Regarding the influence of the parents' level of education on the student's admission into higher education, the data show that $61.4 \%$ of mothers and $73.2 \%$ of fathers had not started a higher education course. We can then assume that other factors are responsible for this influence, such as demand from the job market.

It is interesting to note that $61.4 \%$ of students come from public schools, which may be justified by the majority of students (45\%) having a family income below $R \$ 2,000.00$. Even in face of this context, $54.1 \%$ engage in other activities apart from studying, whether paid or unpaid.

Regarding the process of course adaptation, most students (66.4\%) stated that the educational institution offered adequate conditions for this process, either through lectures on the course or on the institution, as well as through monitoring by the coordination, among other actions (Table4).

\begin{tabular}{|c|c|c|c|}
\hline Variable & Category & $\mathrm{N}$ & $\%$ \\
\hline \multirow{4}{*}{ Age range (years) } & $<20$ & 120 & 54,5 \\
\hline & $20-25$ & 57 & 25,9 \\
\hline & $25-30$ & 19 & 8,6 \\
\hline & $>30$ & 24 & 10,9 \\
\hline \multirow{2}{*}{ Sex } & $\mathrm{F}$ & 101 & 45,9 \\
\hline & $M$ & 119 & 54,1 \\
\hline
\end{tabular}




\begin{tabular}{|c|c|c|c|}
\hline \multirow{6}{*}{ Marital status } & Single & 190 & 86,4 \\
\hline & Married & 19 & 8,6 \\
\hline & Stable Union & 6 & 2,7 \\
\hline & Widowed & 0 & 0 \\
\hline & Divorced & 4 & 1,8 \\
\hline & $\mathrm{NI}^{*}$ & 1 & 0,5 \\
\hline \multirow{7}{*}{ Mother's level of education } & Incomplete Elementary Education & 49 & 22,3 \\
\hline & Complete Elementary Education & 9 & 4,1 \\
\hline & Incomplete High School & 8 & 3,6 \\
\hline & Complete High School & 69 & 31,4 \\
\hline & Incomplete Higher Education & 30 & 13,6 \\
\hline & Complete Higher Education & 54 & 24,5 \\
\hline & $\mathrm{NI}^{*}$ & 1 & 0,5 \\
\hline \multirow{7}{*}{ Father's level of education } & Incomplete Elementary Education & 78 & 35,5 \\
\hline & Complete Elementary Education & 15 & 6,8 \\
\hline & Incomplete High School & 9 & 4,1 \\
\hline & Complete High School & 59 & 26,8 \\
\hline & Incomplete Higher Education & 12 & 5,5 \\
\hline & Complete Higher Education & 44 & 20,0 \\
\hline & $\mathrm{NI}^{*}$ & 3 & 1,4 \\
\hline \multirow{5}{*}{ Family income range } & Up to $R \$ 2.0000,00$ & 99 & 45,0 \\
\hline & From $R \$ 2.000,01$ to $R \$ 4.000,00$ & 58 & 26,4 \\
\hline & From $R \$ 4.000,01$ to $R \$ 6.000,00$ & 30 & 13,6 \\
\hline & Over $\mathrm{R} \$ 6.000,01$ & 31 & 14,1 \\
\hline & $\mathrm{NI}^{*}$ & 2 & 0,9 \\
\hline \multirow{3}{*}{$\begin{array}{l}\text { Type of school where you attended } \\
\text { most of high school }\end{array}$} & Public & 135 & 61,4 \\
\hline & Private & 85 & 38,6 \\
\hline & $\mathrm{NI}^{*}$ & 0 & 0 \\
\hline \multirow{3}{*}{$\begin{array}{l}\text { Apart from studying do you engage in } \\
\text { any other activity? }\end{array}$} & Yes & 119 & 54,1 \\
\hline & No & 101 & 45,9 \\
\hline & $\mathrm{NI}^{*}$ & 0 & 0,0 \\
\hline
\end{tabular}

Source: Research data (2019)

According to Porto and Soares (2017), Higher Education Institutions play an important role for undergraduate students and therefore they must act not only in the initial student integration and adaptation process, but throughout the academic journey, through resources that provide the necessary experiences for a successful academic training, such as the offer of academic scholarships, practical activities and financial aid.

Table 4-Course adaptation

\begin{tabular}{|c|c|c|c|}
\hline \multicolumn{2}{|r|}{ Discrimination } & $\mathrm{N}$ & $\%$ \\
\hline \multirow{3}{*}{$\begin{array}{l}\text { At the beginning of the course, } \\
\text { did the educational institution } \\
\text { offer adequate conditions for } \\
\text { you to adapt to academic life? }\end{array}$} & Yes & 146 & 66,4 \\
\hline & No & 73 & 33,2 \\
\hline & $\mathrm{NI}{ }^{*}$ & 1 & 0,5 \\
\hline \multirow{6}{*}{$\begin{array}{l}\text { How did the process of } \\
\text { adaptation to an academic life } \\
\text { take place? }\end{array}$} & Lectures about the course & 62 & - \\
\hline & Lectures about the course and the institution & 107 & - \\
\hline & Monitoring on the part of the coordination during the first days in the course & 53 & - \\
\hline & Monitoring on the part of the coordination for almost the entire semester & 10 & - \\
\hline & Others & 36 & - \\
\hline & $\mathrm{N} l^{*}$ & 19 & 0 \\
\hline
\end{tabular}

*Not Informed

Source: Research data (2019) 
Table 5 shows the research result regarding interpersonal relationships. In general, students have a positive view of the items analyzed, since more than half of respondents considered interpersonal relationships between colleagues, teachers and the institution as good or very good, with $77 \%, 72 \%$ and $69 \%$ respectively. As for study routines, students showed no major concerns (59\%). Regarding the course coordination, $47 \%$ of respondents said they had a regular, bad or terrible relationship, which should be carefully analyzed by administrators, since a good relationship with the coordination can facilitate the student's adaptation process.

Table 5 - Interpersonal Relationships and Study Routines

\begin{tabular}{|c|c|c|c|c|c|c|}
\hline \multirow{2}{*}{ Identification } & \multicolumn{7}{|c|}{ Relationship Qualification } \\
\cline { 2 - 7 } & Very good & Good & Regular & Bad & Terrible & $\mathrm{Nl}^{*}$ \\
\hline Classmates & 68 & 101 & 48 & 2 & 0 & 1 \\
\hline Professors & 39 & 119 & 56 & 5 & 0 & 1 \\
\hline Coordination & 24 & 90 & 95 & 6 & 3 & 2 \\
\hline Institution & 42 & 110 & 55 & 6 & 3 & 4 \\
\hline Study Routine & 28 & 102 & 69 & 12 & 8 & 1 \\
\hline
\end{tabular}

Source: Research data (2019)

The third part of the questionnaire aimed to identify the possible reasons that would lead students to eventually drop out. For this, respondents were asked to give a score from 0 to 10 for the 20 items in the questionnaire (Table 6).

Table 6 - Reasons for dropping out

\begin{tabular}{|c|c|c|c|c|c|c|}
\hline Variable & Mean & Standard Deviation & Median & Mode & Mininum & Maximum \\
\hline Lack of motivation to continue the course. & 5,07 & 3,46 & 5 & 10 & 0 & 10 \\
\hline Difficulty in following the contents taught. & 5,24 & 3,07 & 6 & 7 & 0 & 10 \\
\hline $\begin{array}{l}\text { Difficulty in following the course due to the time required for } \\
\text { studies. }\end{array}$ & 5,58 & 3,10 & 6 & 5 & 0 & 10 \\
\hline You realized you would not feel well in the profession. & 3,99 & 3,41 & 3 & 0 & 0 & 10 \\
\hline Teachers' teaching skills deficiency. & 4,65 & 3,14 & 5 & 5 & 0 & 10 \\
\hline $\begin{array}{l}\text { You enrolled in the course because you passed the selection } \\
\text { process, but in fact this was not your choice. }\end{array}$ & 3,58 & 3,92 & 1 & 0 & 0 & 10 \\
\hline The course is not what you envisioned. & 3,77 & 3,45 & 3 & 0 & 0 & 10 \\
\hline Deficiencies in the infrastructure of the institution. & 3,72 & 3,15 & 3 & 1 & 0 & 10 \\
\hline $\begin{array}{l}\text { Poor academic performance (your grades are not enough for you } \\
\text { to pass the subjects). }\end{array}$ & 4,01 & 3,46 & 3 & 0 & 0 & 10 \\
\hline Teachers do not give enough attention (lack of receptivity) & 4,09 & 3,05 & 4 & 1 & 0 & 10 \\
\hline $\begin{array}{l}\text { Still unsure if this profession will offer the financial return you } \\
\text { want. }\end{array}$ & 3,95 & 3,33 & 4 & 0 & 0 & 10 \\
\hline $\begin{array}{l}\text { The institution does not offer support for you to adapt to the pace } \\
\text { of university life. }\end{array}$ & 4,60 & 3,15 & 5 & 6 & 0 & 10 \\
\hline Little emphasis on vocational (technical) subjects. & 4,92 & 3,20 & 5 & 5 & 0 & 10 \\
\hline Difficulty in following the course due to lack of financial resources. & 4,47 & 3,56 & 4 & 0 & 0 & 10 \\
\hline Loss of prestige of the accounting career. & 3,16 & 2,93 & 2 & 0 & 0 & 10 \\
\hline Outdated course curriculum. & 3,83 & 3,34 & 3 & 0 & 0 & 10 \\
\hline Difficulty in adapting to the university system. & 3,65 & 3,19 & 3 & 0 & 0 & 10 \\
\hline $\begin{array}{l}\text { The educational institution does not provide information about } \\
\text { the course. }\end{array}$ & 3,28 & 3,03 & 2 & 0 & 0 & 10 \\
\hline Difficulty inbalancing class schedule and professional activities. & 4,86 & 3,63 & 5 & 0 & 0 & 10 \\
\hline Isolation (you cannot make friends with your classmates). & 3,62 & 4,48 & 3 & 0 & 0 & 10 \\
\hline
\end{tabular}

Source: Research data (2019) 
Regarding position measurements, the mean ranged between 3.16 and 5.58, the mode between 0 and 10 and the median between 1 and 6 . As for dispersion measures, the standard deviation ranged between 2.93 and 4.48. The data from the respondents made it possible to identify that 3 items had an average above 5, which may signal that they are relevant reasons. They are: difficulty in following the course due to the time required for the studies, with average 5.58 and standard deviation 3.10 , difficulty in following the content taught, with average 5.24 and standard deviation 3.07, and lack of motivation to continue the course, averaging 5.07 and standard deviation 3.46. It is worth mentioning that this last factor was rated 10 more frequently. The following group averaged 4.1 to 4.92 and comprised 7 factors. Among the items that had means between 3.16 and 3.99, there are 10 factors, which involved questions related to the institution, course and career perspectives.

The factor "difficulty in following the course due to the time required for studies", which had the highest average among the answers, can be justified by the result obtained by asking if the student engages in another activity, whether paid or not (54.1\%).

4.2 Factor analysis

We performed factor analysis for the purpose of identifying the groups of factors among the twenty sentences (variables) present in the research instrument, in order to capture the possible determinant factors for the dropout of Accounting students. Factor analysis is a multivariate interdependence technique that aims to summarize the observed relationships between a set of interrelated variables in order to identify common factors (Fávero, Belfiore, Silva and Chan, 2009).

Initially, we performed the analysis using the main component extraction method from the correlation matrix, without specifying the number of factors. In addition, we used a scree plot as a criterion for the selection of the amount of common factors. This technique considers as major components the factors prior to the curve's inflection point, identifying the optimal number of factors that can be extracted before the single variance amount starts to dominate over the common variance structure (Hair, Anderson, Tatham and Black, 2009). Analyzing Figure 1, three factors were identified.

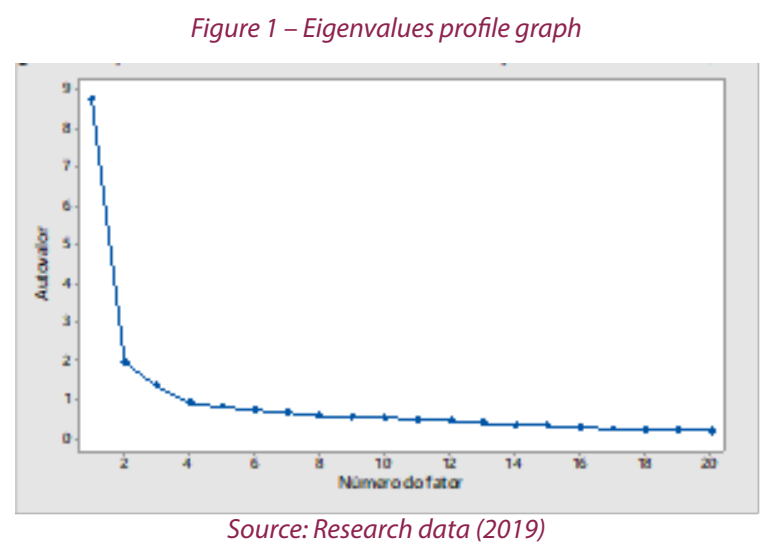

The three defined factors explained $60.4 \%$ of the total variation of the original data. Table 7 presents the eigenvalues result, the percentage of variance explained by each variable and the percentage of variance accumulated by them. When analyzing the commonality values of the variables, it was observed that, with the exception of Sentence 20"S20 - Isolation (you cannot make friends with your colleagues)", which presented commonality equal to 0.364 , all values of commonality rates were higher than 0.500 , 
which demonstrates a degree of explanation of the variables that may be useful in the assessment of dropout factors.

It must be observed that the Kaiser-Meyer-Olklin (KMO) test presented a value of 0.925 , which is considered excellent according to Friel (2009), and that the Bartlett's test presented a significance lower than the level of $1 \%$, indicating a correlation level that is sufficient for the execution of the Factor analysis.

Table 7 - Result of eigenvalues, commonalities and percentage of total variance explained by the three factors

\begin{tabular}{|c|c|c|c|c|c|c|c|}
\hline \multicolumn{2}{|c|}{ Components } & \multicolumn{2}{|c|}{ Eigenvalue } & \multicolumn{2}{|c|}{$\%$ of Variance } & \multicolumn{2}{|c|}{ Cumulative Variance } \\
\hline \multicolumn{2}{|c|}{1} & \multicolumn{2}{|c|}{8,749} & \multicolumn{2}{|c|}{21,5} & \multicolumn{2}{|c|}{21,5} \\
\hline \multicolumn{2}{|c|}{2} & \multicolumn{2}{|c|}{1,957} & \multicolumn{2}{|c|}{20,6} & \multicolumn{2}{|c|}{42,1} \\
\hline \multicolumn{2}{|c|}{3} & \multicolumn{2}{|c|}{1,353} & \multicolumn{2}{|c|}{18,3} & \multicolumn{2}{|c|}{60,4} \\
\hline Variable & Commonality & Variable & Commonality & Variable & Commonality & Variable & Commonality \\
\hline S01 & 0,570 & S06 & 0,734 & S01 & 0,570 & S06 & 0,734 \\
\hline 502 & 0,664 & S07 & 0,703 & S02 & 0,664 & S07 & 0,703 \\
\hline $\mathrm{S} 03$ & 0,657 & 508 & 0,564 & $\mathrm{~S} 03$ & 0,657 & S08 & 0,564 \\
\hline S04 & 0,715 & S09 & 0,649 & S04 & 0,715 & S09 & 0,649 \\
\hline S05 & 0,570 & S10 & 0,723 & S05 & 0,570 & S10 & 0,723 \\
\hline
\end{tabular}

Source: Research data (2019)

Table 8 shows the factor loadings, representing the relationship of each of the variables with their respective factors. The factor loadings close to -1 or 1 indicate that the factor strongly influences the variable. Therefore, the higher the factorial loading of the variable (sentence), the greater the correlation with a given factor. A negative value indicates an inverse impact on the factor. In bold are the factor values with the highest value for the sentences under analysis.

To arrive at the factors, we utilized the Varimax type rotation with extraction by the principal components method. Varimax is a method that minimizes the number of variables with high loads on the given factor, which reinforces the interpretability of the factors (Malhotra, 2011). According to Kline (1994), factor loadings greater than 0.30 are acceptable and above 0.5 are high (Alexander, Brewin, Vearnals, Wolff and Leff, 1999). In this work, the composition of the factors was based on the selection of variables with loadings greater than or equal to 0.4 . Therefore, all sentences were significant in explaining the factors, as follows: Factor 1 - Vocational; Factor 2 - Institutional; Factor 3 - Performance.

Table 8 - Factorial Analysis (Varimax Rotation)

\begin{tabular}{|l|c|c|c|}
\hline \multicolumn{1}{|c|}{ VARIABLES (Sentences) } & \multicolumn{3}{|c|}{ F A CT ORS } \\
\cline { 2 - 4 } & 1 & 2 \\
\cline { 2 - 4 } & Vocational & instittutional & Performance \\
\hline S04 - You realized you would not feel well in the profession & 0,780 & $-0,073$ & $-0,318$ \\
\hline $\begin{array}{l}\text { S06 - You entered the course because you passed the selection process, but in fact this was } \\
\text { not your choice }\end{array}$ & 0,852 & $-0,022$ \\
\hline S07 - The course is not what you envisioned & 0,681 & $-0,050$ & $-0,085$ \\
\hline S11 - Still unsure if this profession will offer the financial return you want & 0,657 & $-0,370$ & $-0,486$ \\
\hline S14 -Difficulty in following the course due to lack of financial resources & 0,539 & $-0,486$ & $-0,114$ \\
\hline S15 - Loss of prestige of the accounting career & 0,591 & $-0,503$ & $-0,137$ \\
\hline S17 -Difficulty in adapting to the university system & 0,526 & $-0,462$ & $-0,143$ \\
\hline S20 - Isolation (you cannot make friends with your classmates) & 0,474 & $-0,295$ & $-0,227$ \\
\hline S05 - Teachers' teaching skills deficiency & 0,083 & $-0,622$ & $-0,421$ \\
\hline S08 - Deficiencies in the infrastructure of the institution & 0,135 & $-0,707$ & $-0,213$ \\
\hline S10 - Teachers do not give enough attention (lack of receptivity) & 0,185 & $-0,701$ & $-0,444$ \\
\hline
\end{tabular}




\begin{tabular}{|l|c|c|c|}
\hline S12 - The institution does not offer support for you to adapt to the pace of the university life & 0,042 & $-0,607$ & $-0,427$ \\
\hline S16 - Outdated course curriculum. & 0,226 & $-0,729$ & $-0,181$ \\
\hline S18 - The educational institution does not provide information about the course & 0,201 & $-0,763$ & $-0,017$ \\
\hline S01 - Lack of motivation to continue the course & 0,378 & $-0,132$ & $-0,640$ \\
\hline S02 - Difficulty in following the contents taught & 0,460 & $-0,130$ & $-0,660$ \\
\hline S03 - Difficulty in following the course due to the time required for studies & 0,247 & $-0,295$ & $-0,713$ \\
\hline S09- Poor academic performance (your grades are not enough for you to pass the subjects) & 0,524 & $-0,192$ & $-0,581$ \\
\hline S13 - Little emphasis on vocational (technical) subjects & $-0,057$ & $-0,324$ & $-0,679$ \\
\hline S19- Difficulty in balancing class schedule and professional activities & 0,271 & $-0,239$ & $-0,612$ \\
\hline
\end{tabular}

Source: Research data (2019)

\subsection{Discussion of results}

Through the application of factor analysis it was possible to define three constructs that summarize the reasons for student dropout: the vocational factor, the institutional factor and the performance factor.

The 20 sentences of the research tool applied presented a negative result when correlated with the institutional and performance constructs. According to Dancey and Reidy (2006, p. 442) "Sometimes it becomes difficult to interpret negative loadings. [...] Usually, a negative loading only means that the variable in question is expressed in a negative way", which fits this study.

However, the same sentences that were declared negatively were positively correlated with the vocational construct, leading us to believe that this result was due to the aptitudes, interests, expectations and personal feelings of the students. We believe that the fact that the research was carried out in the Northeast region, a place with great social inequality, makes the aspects that involve professional career have a great impact for the students, since professional success is seen as one of the factors responsible for financial stability and personal fulfillment.

Through an individual analysis of the constructs, we observed that the vocational factor was the one that had the greatest explanation for the data variability, as it reached the value of $21.5 \%$ in variance, which differs from the findings of Cunha, Nascimento and Durso (2016), whose research developed in the Southeast region presented the institutional factor as the most explanatory. The item within the vocational factor with the highest factor loading is "you entered the course because you passed the selection process, but in fact this was not your choice", which corroborates the findings of Hoffmann et al. (2016), who identified the factor "failure when properly choosing a course" as the one that most motivates the dropout from higher education, according to experts and Cunha, et al. (2016).

The Unified Selection System (SiSu), adopted by federal universities to fill the vacancies offered, is a factor that greatly contributes to this phenomenon, since it allows the student who has not attained the required profile for his or her desired course to choose another course. In addition, this system also negatively impacts the filling of vacancies by those who are actually interested in the desired area.

We observed, then, that, on the one hand, SiSu is a tool that contributes to the democratization of higher education, but, on the other hand, it may contribute to the dropout phenomenon as well.

The institutional factor, which, according to Ambiel (2015), involves faculty and infrastructure, was responsible for explaining $20.6 \%$ of the variation of the data analyzed and considered more relevant. However, it is necessary to highlight that, as previously mentioned, the variables are negatively associated with the aforementioned factor, diverging from the findings of Cunha, Nascimento and Durso (2016) for the Southeast region of Brazil. This may be due to the specificities of the Northeast region, 
where this research was applied, which, according to Franco (2016), has historically suffered from the lack of public investments and from social inequality related to poor educational distribution, despite recent educational policies for higher education developed by the Federal Government in the last decades of the 2000's.

Moreover, in the view of the students researched, "the educational institution does not provide information about the course", which partially converges with the findings of Silva et al. (2018), who identified that HEls tended to have a lower dropout rate when the coordination provided guidance on the course at enrollment, among other actions.

The aspects related to the institution need to be given special attention by the coordination, because the student may be unmotivated if he or she does not have enough information about the enrolled course. Knowing how the course works, its curriculum and other information is of fundamental importance for the student to feel confident that he or she has chosen the right course.

The performance factor presented the least explanation for the data variability, as it reached the value of $18.3 \%$ in variance, but a very close value to the other identified factors. Vasconcelos, Silva and Miranda (2013) affirm that student dropout may be caused by an unsatisfactory performance by students that come from a precarious high school system, and emphasize the issue of students' difficulty in balancing time between studies and work, since the latter often ends up weighing heavier due to students needing to make a living.

In the students' perception, the item "difficulty in following the course due to the time required for studies" has the greatest factor loading, reflecting the reality of many students in the Northeast region, who, despite the existence of policies that facilitated access to high-quality higher education, still need to work to help their families and to fulfill their personal needs.

The results show that institutions need to be more attentive to all aspects that surround the student during his or her undergraduate process, especially in the first semesters, since these are the moments when the students are adapting and moving from a more dependent education system to a more autonomous teaching style common to universities.

\section{CONCLUSION}

This research consisted of a study with students entering the Accounting Sciences courses of Federal Higher Education Institutions (IFES) of the Northeast region. The results indicated that of the 220 respondents, $54.5 \%$ are under 20 years old, mostly male and coming from public education (61.4\%). It was also found that the income of $45 \%$ of respondents is less than $R \$ 2,000.00$ and that $54 \%$ engage in some activity (paid or unpaid) apart from studying. Regarding the adaptation to the course, $66.4 \%$ said that the institution offered adequate conditions for this process.

We noticed that the student profile identified through this study reflects the results of policies that target access to higher education, with the increase of the presence of students who come from public education and have a per capita income below a minimum wage and a half. Therefore, institutions need to be attentive to the demands of this new public that comes with an influx of difficulties and new challenges to attend and remain in higher education.

Regarding interpersonal relationships with peers, teachers, coordination, institution and study routine, the results showed a positive view of the respondents, with the relationship with colleagues and teachers being a highlight, as it showed positive results for $77 \%$ and $72 \%$ of the students researched 
respectively. However, it is necessary to pay more attention to the coordination/student relationship, which was pointed out by $47 \%$ of respondents as being regular, bad or terrible.

A good relationship between the coordination and student can facilitate the student's adaptation process.Moreover, the coordinator fills an intermediary role between the institution and the student, being able to report the student demands to the bodies that are able to promote the changes and consequently make the student career less stressful from the institutional point of view.

As for the possible factors that could lead students to eventually drop out, of the 20 presented, 10 were not strong influencers, being questions related to the institution and course and profession perspectives. A group comprising 7 factors, including difficulties in reconciling class time with work activities, difficulties in following the course due to lack of financial resources and little emphasis on vocational subjects, had median values.

Among the factors considered by the respondents as having the greatest influence on dropout are: "difficulty in following the course due to the time required for the studies", "difficulty in following up the taught content" and "lack of motivation to continue the course", the latter being the one with the highest 10-grade frequency.

Although the aforementioned factors are related to the individual characteristics and skills of each student, the institutions, with this information, can promote actions, such as motivational lectures and study groups, aiming to contribute positively to the students' academic careers, even to the point ofcurbing a possible dropout.

The factor analysis showed that, of all the 20 factors mentioned, only the one that corresponds to the difficulty of establishing friendship with colleagues did not show any degree of explanation of the variables that could be useful in the evaluation of the dropout factors. In the vocational factors group, the item "you entered the course because you passed the selection process, but, in fact, this was not your choice" was the one that showed the highest factorial loading, and can be considered the one that most motivates dropout in this category. The institutional factor that presented the most relevant factor loading was "the educational institution does not provide information about the course".

Finally, in performance-related factors, the item with the highest factorial loading was "difficulty in following the course due to the time required for studies". The reported lack of time may be justified by the significant portion of students (54.1\%) that admitted engaging in another activity (paid or unpaid). In general, the research showed that, in the view of the respondents, the reasons listed influence on the student's decision to leave the course to a greater or lesser extent.

As a suggestion for future studies, we highlight the evaluation of the same factors with students who have actually dropped out in order to make a comparison between the factors listed by incoming students and their degree of influence on dropout and the factors that actually led the students to make the decision to abandon the course.

\section{REFERENCE}

Alexander, B., Brewin, C. R., Vearnals, S., Wolff, G., \&Leff.J. (1999).An investigation of shame and guilt in a depressed sample.British Journal os Medical Psychology. V. 72, 323-38.

Ambiel, R. A. M. (2015). Construção da Escala de Motivos para Evasão do Ensino Superior. Avaliação Psicológica, v. 14, n.1, 41-52. Disponível em:<http://pepsic.bvsalud.org/pdf/avp/v14n1/v14n1a06.pdf> Acesso em: 18 jun. 2019.

Ambiel, R. A. M., Carvalho, L. de F., Moreira, T. da C., \&Bacan, A. R. (2016). Funcionamento diferencial dos itens na Escala de Motivos para Evasão do Ensino Superior (M-ES) Psico, v. 47, n. 1, p. 68-76. 
Ambiel, R. A. M., Santos, A. A. A. dos, \&Dalbosco, S. N. P. (2016). Motivos para evasão, vivências acadêmicas e adaptabilidade de carreira em universitários. Psico, v. 47, n. 4, 288-297.

Araújo, A. M., Almeida, L. S., Costa, A. R., Alfonso, S., Conde, Á., \&Deaño, M. (2015). Variáveis pessoais e socioculturais de diferenciação das expectativas académicas: Estudo com alunos do Ensino Superior do Norte de Portugal e Galiza. Revista Portuguesa De Educação, 28(1), 201-220. https://doi.org/10.21814/ rpe.7057

Beuren, I, M. (Org.). (2008). Como elaborar trabalhos monográficos em contabilidade: teoria e prática. 3 ed., São Paulo: Atlas.

Brasil. (1997). Comissão Especial de Estudos sobre a Evasão nas Universidades Públicas Brasileiras. Diplomação, retenção e evasão nos cursos de graduação em instituições de Ensino Superior públicas. Brasília, DF, Brasil.

Brasil. (2007). Decreto 6.096, de 24 de abril de 2007. Institui o Programa de Apoio a Planos de Reestruturação e Expansão das Universidades Federais - REUNI. Diário Oficial da União. Poder Executivo. Brasília, DF.

Cislaghi, R. (2008). Um modelo de sistema de gestão do conhecimento em um framworkpara a promoção da permanência discente no ensino de graduação. Tese (Doutorado em Engenharia e Gestão do Conhecimento) - Programa de Pós-Graduação em Engenharia e Gestão do Conhecimento, Universidade Federal de Santa Catarina, Santa Catarina, PR, Brasil.

Cunha, J. V. A., Nascimento, E. M., \&Durso, S. O. (2016). Razões e Influências para a Evasão Universitária: um Estudo com Estudantes Ingressantes nos Cursos de Ciências Contábeis de Instituições Públicas Federais da Região Sudeste. Advances in Scientific and Applied Accounting, v. 9, n. 2, 141-161.

Dancey, C.; Reidy, J.(2006). Estatística sem matemática para psicologia. Porto Alegre: Artmed

Fávero, L. P., Belfiore, P., Silva, F. L. da, \& Chan, B. L. (2009).Análise de dados: modelagem multivariada para tomada de decisões. Rio de Janeiro: Elsevier.

Franco, L. C. (2016). Evasão nos Cursos Superiores da Região Norte e estudo comparativo para avaliação das Ifes Tocantinenses. Dissertação (Mestrado Profissional em Gestão de Políticas Públicas), Programa de Pós-Graduação em Gestão de Políticas Públicas, Universidade Federal do Tocantins, Palmas, TO, Brasil.

Friel, C. M. (2009). Notes on factor analysis. Criminal Justice Center, Sam Houston State University.

Gaioso, N. P. de L. (2005). O fenômeno da evasão escolar na educação superior no Brasil. Dissertação (Mestrado em Educação), Programa de Pós-Graduação em Educação, Universidade Católica de Brasília, Brasília, DF, Brasil.

Gil, A. C. Como elaborar projetos de pesquisa. 5. ed. São Paulo: Atlas, 2010.

Gilioli, R. de S. P. (2016). Evasão em Instituições Federais de Ensino Superior no Brasil: expansão da rede, Sisu e desafios. Estudo Técnico, Câmara dos Deputados. Brasília-DF.

Hair, J. F. Jr., Anderson, R. E., Tatham, R. L. \& Black, W. C. (2009). Análise multivariada de dados. 6. ed. Porto Alegre: Bookman.

Hoffmann, I. L., Nunes, R. C., Muller, F. M., \& Hoffmann, D. de La V. (2016). Metodologia para identificação de fatores estratégicos para acompanhamento sistemático da evasão em cursos de graduação. Revista Gestão Universitária na América Latina (GUAL). Florianópolis, p. 157-179, v. 10, n. 4.

Kline, P. (1994). An easy guide to factor analysis.New York: Routledge.

Lobo, M. B. de C. M. (2012). Panorama da evasão no ensino superior brasileiro: aspectos gerais das causas e soluções. ABMES. Cadernos n. 25. Brasília, DF, Brasil. Disponível em: http://www.institutolobo.org.br/ imagens/pdf/artigos/art_087.pdfAcesso em: 10 nov 2019.

Malhotra, N. K. (2011). Pesquisa de marketing: uma orientação aplicada. 6. ed. Porto Alegre: Bookman.

Maués, Olgaíses Cabral. (2019). Ensino superior na ótica dos organismos internacionais. Educar em Revista, 35(75), 13-30. Epub July 29, 2019.https://dx.doi.org/10.1590/0104-4060.66009 
MEC. (2015). Institucional. Disponível em: http://portal.mec.gov.br/institucional/apresentacao-historia. Acesso em 30 agosto de 2020.

MEC. (2018). Censo da Educação Superior 2018.Disponível em: http://download.inep.gov.br/educacao_superior/censo_superior/documentos/2019/censo_da_educacao_superior_2018-notas_estatisticas.pdf. Acesso em 30 maio de 2019.

Porto, A. M. da S. \& Soares, A. B. (2017). Diferenças entre expectativas e adaptação acadêmica de universitários de diversas áreas do conhecimento. Análise Psicológica, 35(1), 13-24. https://dx.doi.org/10.14417/ ap. 1170

Ristoff, Dilvo. (2014). O novo perfil do campus brasileiro: uma análise do perfil socioeconômico do estudante de graduação. Avaliação: Revista da Avaliação da Educação Superior (Campinas), 19(3), 723-747. https:// doi.org/10.1590/S1414-40772014000300010

Schuarcz, L., Sá, M. P. C. de, Warmuth, D., \&Maçaneiro, M. B. (2014). Secretariar ou não secretariar? Eis a questão: um estudo sobre a evasão no curso de secretariado executivo.Revista de Gestão e Secretariado. São Paulo, v. 5, n. 1, p. 19-41.

Silva, G. B. (2016). A educação superior no regime militar: rupturas ou continuidades?. Cadernos De História, 17(27), 455-474. https://doi.org/10.5752/P.2237-8871.2016v17n27p455

Silva, I. J. A., Miranda, G. J., Leal, E. A., \& Pereira, J. M. (2018). Estratégias das Coordenações dos Cursos de Ciências Contábeis para Combater a Evasão. Revista Universo Contábil, 14(2), 61-81.

Silva, I.,Nasu, V., Leal, E., \& Miranda, G. (2020). Fatores determinantes da evasão nos cursos de ciências contábeis no Brasil. Revista Gestão Universitária na América Latina - GUAL, 13(1), 48-69. doi:https://doi. org/10.5007/1983-4535.2020v13n1p48

Silva, C. C., Cunha, J. V. A., Durso, S. de O.,\& Nascimento, E. M. (2014, outubro). Fatores motivadores de não evasão: análise com estudantes de cursos de graduação em ciências contábeis em instituições de ensino brasileiras. Anais do Seminários em Administração, São Paulo, SP, Brasil, XVII.

Silva Filho, R. L. L., Montejunas, P. R., Hipólito, O.,\& Lobo, M. B. de C. M. (2007). A evasão no ensino superior brasileiro. Cadernos de Pesquisa. São Paulo, v. 37, n. 132, p. 641-659.

Vasconcelos, A. L. F. de S., Silva, M. N. da \& Miranda, N. P. de. (2013). Um estudo sobre as causas da evasão no ensino superior no curso de Ciências Contábeis e Atuariais. Revista Brasileira de Contabilidade, [S.I.], n. 195, p. 20-31, jan. 2013. ISSN 2526-8414. Disponível em: http://rbc.cfc.org.br/index.php/rbc/article/view/991.

Vieria, P.R. da C.,Troccoli, I. R. \& Silva, J. M. C.da. A relevância do corpo docente na qualidade percebida em serviço de ensino superior no Brasil: um estudo com modelagem de equações estruturais. Revista Economia \& Gestão, v. 11, n. 26, p. 82-109, 2011. 